\title{
To leave or not to leave: retirement intentions and retirement behaviour
}

\author{
PER ERIK SOLEM*, ASTRI SYSE*†, TRUDE FURUNES $\ddagger$, \\ REIDAR J. MYKLETUN\$, ANNET DE LANGE $\uparrow$, \\ WILMAR SCHAUFELI $\|$ and JUHANI ILMARINENI
}

\begin{abstract}
Research on the correspondence between retirement intentions and subsequent behaviour is scarce. We aimed to explore possible associations between retirement intentions and behaviour, using five-year high-quality quantitative panel data on Norwegian senior workers. Retirement intentions operate at different levels of firmness: (a) considerations; (b) preferences; and (c) decisions. Compared to work continuation considerations, a targeted age for retirement improved predictive power whether the target was preferred or decided, and particularly so if the target (i.e. the preferred or decided age of retirement), corresponded with a normative retirement age. Because more workers are able to state a preferred age of retiring than a decision about when to retire, preferences may be better proxies for retirement behaviour than decisions, when the issue is planning for policies. The correspondence between intentions and behaviour varies primarily by health, education and type of work. Older workers with poor health, and workers with low education, often retire earlier than they prefer. Blue-collar workers often retire earlier than they had decided. These findings illustrate the possible effect of labour market resources, not only for senior workers' labour market participation, but also for their opportunities to work up to the age they prefer or had decided. Even for white-collar workers and those in good health, constraints seem to apply when they wish to retire late.
\end{abstract}

KEY WORDS-decision-making, older workers, retirement, employment, early retirement, Norway.

* Norwegian Social Research (NOVA), Oslo and Akershus University College of Applied Sciences, Oslo, Norway.

$\dagger$ Statistics Norway, Oslo, Norway.

+ School of Hotel Management, University of Stavanger, Norway.

$\S$ HAN University of Applied Sciences, Nijmegen, The Netherlands.

\| Faculty of Social and Behavioural Sciences, Utrecht University, The Netherlands.

II Juhani Ilmarinen Consulting Ltd, Vantaa, Finland. 


\section{Introduction}

Previous research on ageing and work has focused on factors that predict actual early and late retirement or preferences for early or late retirement among senior workers (Loretto, Vickerstaff and White 2007; Midtsundstad 2006; Solem 2007; van Solinge and Henkens 2014). We know more about how preferences for retirement timing are distributed than how such preferences predict retirement behaviour (Örestig, Strandh and Stattin 2013). Increasingly, retirement is, compared to the former standardised retirement regimes, a process that occurs over a span of time and that involves a series of reflections and decisions concerning timing and form of retirement (Moen 2012). However, a lack of research exists on the complex decision-making processes that precede actual retirement (Phillipson and Smith 2005). One study by Ekerdt et al. (2001), from the United States of America, found that retirement decisions among many older workers involve a process of hesitation and doubt. This is confirmed by Solem's (1989) Norwegian study in which decisions were found to change frequently close to the time of actual retirement among persons with ambivalent emotions towards retirement.

Limited research exists on the correspondence between retirement intentions and subsequent behaviour (Henkens and Tazelaar 1997; van Solinge and Henkens 2009), whereas more research has examined antecedents and consequences of retirement preferences and decisions, respectively (Topa et al. 2009). Beehr's (1986) and Feldman and Beehr's (2011) retirement process model distinguishes between preferences, intentions and the act of retiring, and describes a process of increasing decisiveness. In the present study, we apply the retirement process model with some modifications. Increased knowledge about the retirement process is important because policies aimed to delay retirement are implemented in many countries due to ageing populations and increasing pension costs, which pressure welfare states both economically and non-economically (Christensen et al. 2012; Quinn, Cahill and Giandrea 2011).

The objective of this article is to identify factors that influence the correspondence between older workers' retirement intentions and subsequent behaviour and explore possible relationships between three levels of firmness of retirement intentions, expressed as considerations, preferences or decisions, and future behaviour. For instance, 'I shall consider continuing to work when I reach the eligible age for pension', is expected to be less predictive of retirement behaviour than is, 'I have decided to retire at the age of 65 '. This hypothesis is in accordance with Ajzen's (1988, 2011) general observation that predictive power increases with the specificity of the behaviour to be predicted. This principle has also been confirmed 
specifically for retirement behaviour (Anderson, Burkhauser and Quinn 1986; Prothero and Beach 1984).

Prothero and Beach (1984) described an expectation-intention-action chain of retirement decisions. Within a two-year period, expectations about retirement predicted intentions to retire, and intentions subsequently predicted retirement behaviour. These predictions were, however, less than perfect and misprediction was partly attributable to policy amendments that changed both the opportunity structure and the expectations of older workers. Longer time lags between expectations, intentions and actions increase the probability of changes in the opportunity structure and expectations, and result in less accurate predictions.

However, Henkens and Tazelaar (1997) found no time-lag effect between stated intentions to retire and actual retirement within a three-year period. Thus, time is expected to increase the probability of changes in the opportunity structure; however, if no significant changes occur, duration does not appear to be sufficient to sever the connection between stated intentions and subsequent behaviour. Correspondence between preferences and behaviour also seems influenced by how well the preference question specifies a realistic context, as found in a Swedish panel study that situated the preference to the respondents' health, economy, work and retirement regulations (Örestig, Strandh and Stattin 2013).

\section{Theoretical background}

According to Ajzen's (1988) theory of planned behaviour, decisions or intentions are based on three considerations: (a) behaviour beliefs (i.e. the subjective probability that the behaviour will produce a preferred result); (b) normative beliefs (i.e. beliefs about the normative expectations of others); and (c) control beliefs (i.e. beliefs about the ability to perform the required action). Behaviour beliefs may concern the subjective probability of enjoying life more if retiring than if remaining on the labour market. Normative beliefs concern socially expected ages of retirement; in Norway retirement is peaking at 62 and 67 years as pensions are available within two different pension systems from these ages. Control beliefs concern agency and the opportunity structure, which includes ability to perform the act of retiring or to remain in the labour market under the current pension regime, working conditions, family situation, personal health and work ability.

While this is the general model, detailed considerations must come into play as retirement decisions have become increasingly complex because of multiple changes in rules and regulations in a vast number of countries over 
the last decade (Micheel, Roloff and Wickenheiser 2010). For the majority of Norwegian workers, the national old age pensions are-since 2011-optional between ages 62 and 75 (Christensen et al. 2012). However, the 2011 pension reform left mandatory retirement age untouched at the age of 70 (Kjønstad 2012). Thus, Norwegian workers have a right to start take-up of the national pension whenever they wish within the $62-75$ age limit, and at the same time to work for pay with no income test on their pensions. However, the right to remain in a job is limited to the age of 70 as the mandatory retirement age. Thus, Norway has replaced the formal pension age of 67 with a flexible pension period, while most of the 34 countries in the Organisation for Economic Co-operation and Development (OECD) have increased or plan to increase their pension age (OECD 2011a).

Governments in many countries are presently promoting norms for prescribing late retirement and introducing incentives to support such norms (Micheel, Roloff and Wickenheiser 2010; OECD 2011a, 2011b; Phillipson 2011; Vickerstaff, Loretto and White 2007). However, norms and policies are likely to vary greatly between industries, companies and local workplaces, nationally and internationally (OECD 2011 $a$; Taylor 2010). Norms also vary between socio-economic groups; for instance, between persons with only basic education and those with higher levels of education, as well as between workers employed in different occupations (D'Addio, Keese and Whitehouse 2010; Midtsundstad 2006; Phillipson and Smith 2005). At the same time, many of the reformed pension systems assume that individuals make rational decisions based on economic and non-economic cost-benefit considerations (Becker 1976), whereas empirical research has shown that rational decision-making processes are less commonly applied than are theoretically assumed (Kahneman 2011).

To support late retirement, the revised national pension system in Norway, effective as of 2011 , is based on actuarial principles, including an incentive structure for delayed retirement. Individuals are thought to apply rational thinking and economic and non-economic calculations of cost-benefit to assess adequately which retirement decision is likely to be most beneficial individually, socially and financially. Optimal financial decisions for individuals remain, however, largely unknown as a main premise for calculating the prime time to retire is outside one's control (i.e. the number of years left to live; or in other words, the age at which death occurs).

Subjective life expectancy (van Solinge and Henkens 2009), also termed subjective survival probability (O'Donnell, Teppa and van Doorslaer 2008), is defined as the number of years a person expects to live. The years left to live in good enough health to enjoy spending money, disability-free life expectancy, is also unknown, and a person's subjective disability-free 
life expectancy differs, but is often overly pessimistic and described as 'health pessimism' (Brown and Vickerstaff 2011). Thus, persons expect to have unrealistically few years left to live or they anticipate becoming frail much sooner than turns out to be reality, which may encourage early take-up of pensions and early work exit.

Uncertainties about the future, and the probable uneasiness of planning for one's own finitude, may prevent thoughtful, rational planning. However, the awareness of finitude may be an integrated part of the self-image, and when it is, it is often reported to result in a change of values. Specifically, money and material values seem to be downgraded, according to socioemotional selectivity theory (Carstensen 2006), and the dualistic developmental model (Brandtstädter et al. 2010), while other values, such as social contacts, travel, voluntary work, politics, hobbies or the intrinsic value of work itself, may be upgraded. Paradoxically, financial incentives may become less powerful if senior workers go into depth in the calculation of their future pension uptake to determine the profitability of early versus later retirement. If the pre-retiree carefully considers all options, he or she will be confronted with the finitude of life, which may change his or her values in a way that makes economic benefits less attractive and economic incentives less influential. Therefore, the rational economic considerations upon which the incentive structure of the new pension system rests may be challenged on psychological grounds.

The rationality of retirement decisions may also be challenged by information and decision overload (Ruff 2002; Toffler 1970; Vickerstaff and Cox 2005). Too much detailed information, and strong urges to make decisions based on such details, may nurture resistance and avoidance, and the pre-retiree is thereby exposed to the effects of norms. Older workers may save cognitive effort and energy by simply following experts' recommendations, employer's expectations or the decisions that others make. Nevertheless, unconscious decisions may be better (Dijksterhuis et al. 2006), as people use intuitive knowledge and make allowances for emotional reactions. Thus, emotions and motives may be in conflict as senior workers may be both attracted to retirement and, at the same time, find it repelling.

Psychological theory on motivational conflicts suggests that an approachavoidance conflict may occur when a goal is ambivalent and has both positive and negative incentives (Lewin 1935). A pronounced approach-gradient is present at a distance, while the avoidance-gradient increases rapidly once the goal is closer (Miller 1959). This may explain the tendency for retirement to be more attractive at a distance than closer to 'the moment of truth' for workers who have ambivalent feelings about retiring (Solem 1989).

Good correspondence between intentions and behaviour is expected when intentions are based on rational and realistic conceptions about the 


\section{Per Erik Solem et al.}

probability that the behaviour will produce the preferred results, and when the norms that regulate behaviour are adhered to and opportunities to perform the desired action exist. Correspondence is expected to be low if rationality is challenged; for example, by erroneous expectations about healthy life expectancy, decision overload or the span of time to the 'moment of truth'. In a recent review, Jex and Grosch (2013) deemed that there is enough irrationality in retirement decision-making to warrant the attention of researchers. Correspondence may also decrease if selfdetermination is blocked by a loss of resources (e.g. health deteriorations that limit the opportunity structure). Taken together, these limitations demonstrate that the correspondence between intentions and behaviour rarely will be perfect.

\section{Research questions}

In this study, we ask whether a correspondence exists between retirement intentions and subsequent retirement behaviour. We examine the effects of intentions on behaviour at three specific strength levels:

1. Consideration to remain at work beyond the eligible age for pension.

2. Preference to retire at a certain self-specified age.

3. Decision to retire at a certain self-specified age.

Henkens and Tazelaar (1997: 149) showed being able and/or willing to specify an age for preferred or decided retirement as, 'Far more likely to hit the target than those who said they would not retire early'. Along these lines, we expect that contemplating to remain at work (i.e. not to retire early) is less predictive of retirement behaviour than is specifying an age for preferred or decided retirement, and a decision on the timing of retirement is expected to be more predictive than is a mere preference for a certain retirement age.

Because decisions are supposed to be carried out, the concepts of retirement decisions and behaviour are often used interchangeably. However, in this study, there is a time lag of up to five years between decisions and behaviour. During this period, decisions may change, for instance, due to changes in the opportunity structure. Thus, predictability may depend more on the realism of how the opportunity structure is perceived than on whether the age of retirement is preferred or decided.

Elaborations on the decision processes and how senior workers think (or do not think) about how and when to end their working careers need to be explored through qualitative data collected at the company level. However, our focus is on the correspondence between retirement intentions of various strengths and behaviour, and whether measured intentions may be proxies for actual behaviour. As such, the research question entails 
an important methodological concern. Nevertheless, our research question is also substantial: What is the relation between intentions and behaviour? Or more specifically, to what extent do senior workers act according to their retirement decisions?

\section{Method}

\section{Sample}

Panel data from the Norwegian Study on Life Course, Ageing and Generation (NorLAG1 and NorLAG2; Slagsvold et al. 2012) were used in all analyses. In short, 5,589 persons aged $40-79$ years responded to a telephone interview in the NorLAG1 study, conducted in 2002-03. Registry data from Statistics Norway were linked to the respondents. The response rate in the first round (Time 1, T1 ) was 67 per cent. Among these were 3,328 employed workers, of whom 45 per cent were employed in the public sector. In total, 72 per cent of the individuals interviewed in NorLAG 1 chose to participate in the similarly designed NorLAG2 follow-up study conducted in 2007-o8 (Time 2, T2). The total response rate was 48 per cent, which left a sample of 2,401 workers employed in 2002-03, for which we also have information on actual retirement behaviour in 2007-08. Among these workers, 605 individuals were gainfully employed and 57 years or older in 2002-03. The age limit of 57 was set to secure that all subjects had the option of choosing retirement at age 62 between $\mathrm{T}_{1}$ and $\mathrm{T}_{2}$, and 55 per cent per cent had actually retired in 2007-08. All participating workers were asked questions about their retirement intentions (i.e. considerations, preferences and decisions).

Our study sample consisted of three partly overlapping age groups. In the analyses presented in Table 2, employees in the public sector aged 57-61 years at T1 who stated they had considered either to continue or not continue working after becoming eligible for early retirement were included $(\mathrm{N}=133)$. All public employees in this age group may opt to retire early (i.e. prior to the second wave of data collection in 2007-08), whereas only around $5^{\mathrm{O}-60}$ per cent of employees in the private sector were members of the contractual early pension scheme (AFP), and could opt to retire early (i.e. at age 62). As we are not able to identify in our data concerning which privately employed individuals had the option to retire early, no workers in the private sector were included in this analysis.

\section{Analyses}

In the analyses presented in Tables $3^{-6}$, both public- and private-sector employees were included, and no upper age limit was set. The multivariate 
analyses were restricted to those who stated a preferred retirement age $(\mathrm{N}=309)$ or decided on a retirement age $(\mathrm{N}=184)$, and who had actually retired between $\mathrm{T}_{1}$ and $\mathrm{T}_{2}$.

The correspondence between retirement intentions stated in 2002-03 and subsequent retirement behaviour over the next five years was analysed using descriptive statistics and univariate and multivariate ordinary and multinomial logistic regression models in Stata 12 (StataCorp 2011). Individuals with missing retirement year or retirement intention information were excluded from the relevant sub-analyses. Individuals with missing information on covariates were included in missing categories to enable the inclusion of these individuals in the analyses. Interaction terms were added to the models to explore the extent of effect modification. Stratified analyses were undertaken in which interaction terms indicated that a modification effect was present. The statistical significance level was set at 5 per cent in all analyses.

\section{Measurement of retirement intentions}

Retirement intentions were measured using three questions that examined considerations, preferences and decisions. The three questions were as follows: (a) 'Will you consider continuing to work after you have achieved a right to a pension?'; (b) 'If it were all up to you, at what age would you prefer to retire?'; and (c) 'Have you decided at what age you will quit work and retire? If yes, at what age?' These questions represent three levels of strength of intentions (considerations, preferences and decisions, respectively), listed above from weakest to strongest. The weakest intention is to consider continuing to work after reaching the right to a pension. The next level of strength of intentions is to prefer a certain age for retirement, whereas the strongest intention is to decide at what age to retire. As stated previously, we expected that the stronger the intentions, the stronger the observed effect on the actual retirement behaviour. Answers to these three questions all came from the first round (i.e. at NorLAG1; T1).

\section{Measurement of retirement behaviour}

Measurements of retirement behaviour are based on a comparison between data from the first and second round of data collection (i.e. a comparison of work status in 2002-03 ( $\left.\mathrm{T}_{1}\right)$ and 2007-08 $\left(\mathrm{T}_{2}\right)$ ). To determine whether persons had retired between $\mathrm{T}_{1}$ and $\mathrm{T}_{2}$, the following question was asked at T1: 'Are you currently doing any work for pay?' At T2 the question read: 'Do you consider yourself mainly as an employee, a disability pensioner, 
a recipient of AFP contractual early pension (eligible at ages 62-66), a recipient of early occupational pension (eligible at ages 58-66), or a recipient of a national old age pension (eligible from age 67 )?' The following questions were asked at $\mathrm{T}_{2}$, both to persons working and not working at T1: 'When was the last time you worked for pay?' and 'If you consider yourself as mainly a pensioner, at what point in time did you begin receiving a pension?'

Of those 57 years and older who were working at $\mathrm{T}_{1}$ and became pensioners in the years from 2002 to $2008,5^{8}$ per cent had stopped working during the year they began receiving their pensions. The correlation between year of becoming a pensioner and year of quitting work was 0.46 (Pearson's $r, p<0.01$ ), whereas the correlation between age of becoming a pensioner and age of quitting work was $0.77(p<0.01)$. As the $r$ values are sensitive to the definition of the variables, the discrepancy between the correlation coefficients was, in part, a consequence of the age variable having a wider range than the year variable.

Altogether, 13 per cent stopped working before they began receiving an age-related pension, while 29 per cent continued working after taking their pensions. Thus, it is evident that quitting work and taking a pension do not always occur simultaneously. There is a considerable degree of discrepancy between the point in time at which individuals retire from work and when they take their pensions. This discrepancy is partly due to the inherent flexibility of the pension system (Ekerdt 2010; Shultz and Wang 2011), which is expected to increase in Norway as a consequence of the new national pension scheme effective as of 2011 (Christensen et al. 2012). However, this flexibility is problematic in the operationalisation of retirement behaviour, as discrepancy existed in 42 per cent of the current sample between taking the pension and quitting work. Furthermore, we chose to define retirement from the point in time at which individuals self-reported themselves mainly as pensioners, although they still may have been working for pay to some extent.

\section{Covariates}

The covariates included in our study are described in Table 1, and are all from $\mathrm{T}_{1}$ for the time-variant variables. Data on marital status, parental status, education and income were imported from registries at Statistics Norway. Self-rated health was based on one interview question ('In general, how would you say your health is?' Excellent, very good, good, fair, poor), as was occupation ('What is your occupation in your present job?' and 'What are your main tasks?'). Occupation was categorised according to the EGP scale (Erikson, Goldthorpe and Portocarero; see Leiulfsrud, Bison and 
T A B L E 1. Descriptive statistics in 2002-03 of employed individuals 57 years and older by retirement status in $2007^{-0} 8$

\begin{tabular}{|c|c|c|c|c|}
\hline & Working at Time 2 & Retired at Time 2 & Total & $p$ \\
\hline & \multicolumn{3}{|c|}{ Percentages $(N)$} & \\
\hline Gender: & & & & 0.18 \\
\hline Female & 41.8 & $5^{8.2}$ & $100(285)$ & \\
\hline Male & $47 \cdot 2$ & $5^{2.8}$ & $100(320)$ & \\
\hline Age (range $57-79$ ): & & & & $<0.001$ \\
\hline $57-61$ & $55 \cdot 9$ & $44 \cdot 1$ & $100(399)$ & \\
\hline $62-64$ & 24.2 & 75.8 & $100(128)$ & \\
\hline $65^{+}$ & 20.5 & $79 \cdot 5$ & $100(78)$ & \\
\hline Education: & & & & 0.02 \\
\hline$\leqslant$ Primary school & 42.7 & $57 \cdot 3$ & $100(82)$ & \\
\hline High school & 39.2 & 60.8 & $100(271)$ & \\
\hline$\geqslant$ University/college & $5^{1.2}$ & $4^{8.8}$ & $100\left(25^{2}\right)$ & \\
\hline Marital status: & & & & 0.26 \\
\hline Married/co-habiting & 44.2 & 55.8 & $100(475)$ & \\
\hline Never married & 32.0 & 68.0 & $100(25)$ & \\
\hline Divorced/separated & $54 \cdot 9$ & $45^{.1}$ & $100(71)$ & \\
\hline Widowed & 38.2 & 61.8 & $100(34)$ & \\
\hline Parental status: & & & & 0.64 \\
\hline No children & $4^{2.1}$ & $57 \cdot 9$ & $100(76)$ & \\
\hline Children & $45 \cdot 0$ & 55.0 & $100\left(5^{29}\right)$ & \\
\hline Self-rated health: & & & & $<0.001$ \\
\hline Excellent & $57 \cdot 1$ & 42.9 & $100(163)$ & \\
\hline Very good & 48.3 & $5^{1.7}$ & $100(180)$ & \\
\hline Good & 37.6 & 62.4 & $100(157)$ & \\
\hline Fair & $3^{2.1}$ & $67 \cdot 9$ & $100(81)$ & \\
\hline Poor & 20.8 & 79.2 & $100(24)$ & \\
\hline Type of work: & & & & $<0.001$ \\
\hline White-collar & $5^{1.6}$ & $4^{8.4}$ & $100(322)$ & \\
\hline Blue-collar & 36.7 & $63 \cdot 3$ & $100(283)$ & \\
\hline Income after tax: & & & & $<0.01$ \\
\hline 1st quartile & $4^{6.7}$ & 53.3 & $100\left(15^{2}\right)$ & \\
\hline 2nd quartile & $3^{8.4}$ & 61.6 & $100\left(15^{1}\right)$ & \\
\hline 3rd quartile & 37.8 & 62.2 & $100\left(15^{1}\right)$ & \\
\hline $4^{\text {th }}$ quartile & 55.6 & $44 \cdot 4$ & $100\left(15^{1}\right)$ & \\
\hline
\end{tabular}

Notes: $\mathrm{N}=60_{5}$. Blue- and white-collar categorisations are based on EGP scale (Erikson, Goldthorpe and Portocarero; see Leiulfsrud, Bison and Jensberg 2005) classifications and are referenced in the paper. Persons with missing EGP values $(N=66)$ were included in the blue-collar category.

Jensberg 2005), and dichotomised as white-collar (professionals) versus blue-collar workers (Lima 2011). Private versus public sector was not included as a covariate. The patterns of retirement were not significantly different between sectors, and for the analysis of considering retirement, only the public sector was included. 


\section{Results}

\section{Considering to continue working}

The anticipated weakest correlation was explored first (i.e. the correlation between whether one states at $\mathrm{T}_{1}$ that he or she will consider continuing to work after having reached pensionable age and whether one remains employed at T2. A significantly higher proportion of those who considered continuing work (61 per cent) compared to those who did not consider continuing work (41 per cent) were working at T2 $(p=0.02)$. The correlation between considering to continue working and actually continuing to work five years later was weak ( $r=0.20)$ (Cohen 1988). Similarly, the univariate logistic regression odds ratio (OR) for being retired among those not considering to continue working was 2.29 (95 per cent confidence interval $(\mathrm{CI})=1.14-4.60$ ) (not shown). However, when the relevant covariates were included in a multivariate model, the effect of consideration on actual retirement behaviour became statistically nonsignificant (Table 2). Male gender, older age, blue-collar occupation and not belonging to the lowest income quartile were all independent predictors of being retired at $\mathrm{T}_{2}$, whether considering to continue working or not at $\mathrm{T}_{1}$.

In summary, the results indicate that there appears to be, at best, a weak correlation between the degree to which one will consider continuing to work after becoming eligible for a pension and actually working after the eligibility age among employees in the public sector. Statements of considering to continue working beyond the eligibility age appear to be poor proxies for retirement behaviour within a five-year period.

\section{Preferring to retire at a specific age}

We expected a stronger correlation between preferred age of retirement and actual retirement age. In Table 3, answers to the question 'If it were all up to you, at what age would you prefer to retire?' are compared to the actual age of retirement. The age categories correspond to the eligibility criteria for the main available pensions. At the time of data collection, 62 was the eligible age for contractual early pension, whereas 67 was the eligible age for ordinary old age pension (Kjønstad 2012). A number of individuals who did not retire entirely 'voluntarily' may be represented among those who stated that they retired earlier than preferred. This issue is considered in more detail in the discussion.

The correlation between preferred age of retirement stated at $\mathrm{T} 1$ and selfreported actual age of retirement stated at T2 was strong $\left(r=0.5^{1}\right)$ and highly statistically significant $(p<0.001)$. The preferred age of retirement explained 26 per cent $\left(0.5^{1}\right)$ of the variance in actual age of retirement. 
T A B L E 2. Estimates from a fully adjusted logistic regression model to assess the probability of being retired in 2007-08 (Time 2) among public-sector employees 57-6I years old in 2002-03 (Time I) by their stated work considerations at that time

\begin{tabular}{|c|c|c|c|}
\hline \multirow[b]{2}{*}{ Status at Time 1} & \multicolumn{3}{|c|}{ Probability of being retired at Time 2} \\
\hline & OR & $95 \% \mathrm{CI}$ & $p$ \\
\hline Will consider continuing to working & 1.00 & Ref. & \\
\hline Will not consider continuing to work & 2.09 & $0.88-4.97$ & 0.09 \\
\hline Female & 1.00 & Ref. & \\
\hline Male & 2.77 & $1.09-7.01$ & 0.03 \\
\hline Age (continuous) & 1.76 & $1.24^{-2.4^{8}}$ & $<0.01$ \\
\hline$\geqslant$ University/college & 1.00 & Ref. & \\
\hline$\leqslant$ High school & $2.5^{\circ}$ & $0.86-7.23$ & 0.09 \\
\hline Not married & 1.00 & Ref. & \\
\hline Married & 1.86 & $0.62-5 \cdot 5^{6}$ & 0.27 \\
\hline No children & 1.00 & Ref. & \\
\hline Children & 0.94 & $0.25^{-3} \cdot 5^{1}$ & $0.9^{2}$ \\
\hline Good self-rated health & 1.00 & Ref. & \\
\hline Poor self-rated health & 2.94 & $0.89-9 \cdot 70$ & 0.08 \\
\hline White-collar work & 1.00 & Ref. & \\
\hline Blue-collar work & 6.80 & $2 \cdot 3^{8-19 \cdot 45}$ & $<0.01$ \\
\hline 1st quartile income & 1.00 & Ref. & \\
\hline 2nd quartile income & 3.85 & $1.10-13.53$ & 0.04 \\
\hline 3rd quartile income & 10.34 & $2.12-5^{0.43}$ & $<0.01$ \\
\hline $4^{\text {th }}$ quartile income & $5 \cdot 43$ & $1.10-26.71$ & 0.04 \\
\hline
\end{tabular}

Notes: $\mathrm{N}=133 . R^{2}=0.22,11$ degrees of freedom, $p<0.001$. OR: odds ratio. CI: confidence interval. Ref.: reference category.

This means that the preferred age of retirement was a sub-optimal proxy for actual retirement age. Although this measure predicted age of retirement fairly well and explained 26 per cent of the variance, it does not qualify as an optimal measure of retirement behaviour. The predictive power is, however, improved compared to the predictive power of the weaker 'will consider' statement ( $r=0.20$, explaining 4 per cent of the variance). Preferred age of retirement is a better predictor if the person prefers the normative retirement ages, primarily 67 years (45 per cent did as they preferred), but also for 62 years, which is the eligibility age for contractual early pension (AFP). In the latter case, $3^{8}$ per cent did as they preferred. Preference for more odd retirement ages predict less well, and overall 26 per cent retired at the preferred age. Yet, preferences for early retirement increases the risk of having to retire later than preferred, and preferences for retiring late increases the risk of retiring earlier than preferred. 
T A B L E 3 . A comparison of stated preferred retirement age/other covariates (2002-03) and actual retirement age (2007-08) for employees 57 years and older in 2002-03 who were retired in 2007-o8

\begin{tabular}{|c|c|c|c|c|c|}
\hline & $\begin{array}{l}\text { Retired } \\
\text { earlier than } \\
\text { preferred }\end{array}$ & $\begin{array}{l}\text { Retired at the } \\
\text { preferred age }\end{array}$ & $\begin{array}{l}\text { Retired } \\
\text { later than } \\
\text { preferred }\end{array}$ & Total & $p$ \\
\hline \multicolumn{6}{|c|}{ Percentages $(N)$} \\
\hline Preferred age of retirement: & & & & & $<0.001$ \\
\hline $54^{-61}$ & 11.5 & 9.8 & 78.7 & $100(61)$ & \\
\hline 62 & 15.9 & 37.8 & 46.3 & $100(82)$ & \\
\hline $63-66$ & 12.2 & 21.1 & 66.7 & $100(90)$ & \\
\hline 67 & 29.8 & $44 \cdot 7$ & 25.5 & $100(47)$ & \\
\hline $68-90$ & $79 \cdot 3$ & 13.8 & 6.9 & $100(29)$ & \\
\hline Female & 20.1 & 26.0 & $53 \cdot 9$ & $100(154)$ & \\
\hline Male & $23 \cdot 9$ & 26.5 & $49 \cdot 7$ & $100(155)$ & o.68 \\
\hline$\leqslant$ High school & $24 \cdot 4$ & 22.8 & $5^{2.8}$ & $100(197)$ & \\
\hline$\geqslant$ University/college & $17 \cdot 9$ & 32.1 & $5^{0.0}$ & $100\left(\begin{array}{lll}1 & 12\end{array}\right)$ & 0.15 \\
\hline Not married & $27 \cdot 3$ & 18.2 & $54 \cdot 5$ & $100(66)$ & \\
\hline Married & 20.6 & 28.4 & $5^{1.0}$ & $100(243)$ & 0.20 \\
\hline No children & 19.0 & 21.4 & $59 \cdot 5$ & $100(42)$ & \\
\hline Children & 22.5 & 27.0 & $5^{0.6}$ & $100(267)$ & 0.55 \\
\hline Good self-rated health & 20.0 & 28.6 & $5^{1 \cdot 4}$ & $100(245)$ & \\
\hline Poor self-rated health & $29 \cdot 7$ & 17.2 & 53.1 & $100(64)$ & 0.09 \\
\hline White-collar work & 18.4 & $27 \cdot 9$ & $53 \cdot 7$ & $100(147)$ & \\
\hline Blue-collar work & $25 \cdot 3$ & $24 \cdot 7$ & $5^{0.0}$ & $100(162)$ & 0.33 \\
\hline 1st quartile income & $24 \cdot 4$ & 30.8 & & $100(78)$ & \\
\hline 2nd quartile income & 18.2 & 26.0 & 55.8 & $100(77)$ & \\
\hline 3rd quartile income & 19.5 & 18.2 & 62.3 & $100(77)$ & \\
\hline $4^{\text {th }}$ quartile income & 26.0 & $29 \cdot 9$ & 44.2 & $100(77)$ & 0.25 \\
\hline Total & 22.0 & 26.2 & $5^{1.8}$ & $100(309)$ & \\
\hline
\end{tabular}

In both the univariate (Table 3 ) and multivariate (Table 4 ) models, a high preferred retirement age increased the risk of earlier than preferred actual retirement $(\mathrm{OR}=\mathbf{2 . 2 0})$, and reduced the risk of later than preferred actual retirement $(\mathrm{OR}=0.54)$. In addition, a higher age reduced the risk of retiring earlier than preferred $(\mathrm{OR}=0.55)$ and increased the risk of retiring later than preferred $(\mathrm{OR}=1.66)$. Having obtained only a basic education (limited upwards to high school) increased the risk of retiring earlier than preferred $(\mathrm{OR}=3.13)$ as did poor self-rated health $(\mathrm{OR}=4.26)$ net of preferred retirement age. Blue-collar work also increased the risk of earlier than preferred retirement $(\mathrm{OR}=\mathbf{2 . 8 3})$. Among the included covariates, poor health was the strongest predictor of earlier than preferred retirement, pointing to poor health as a factor that increased the risk of involuntary early retirement. 


\section{Per Erik Solem et al.}

T А В L E 4 . Estimates from a fully adjusted multinomial logistic regression model to assess the probability of retiring at an earlier or later age than preferred

\begin{tabular}{|c|c|c|c|c|c|c|}
\hline \multirow[b]{2}{*}{ Status in $2002-03$} & \multicolumn{3}{|c|}{ Earlier than preferred } & \multicolumn{3}{|c|}{ Later than preferred } \\
\hline & OR & $95 \% \mathrm{CI}$ & $p$ & OR & $95 \% \mathrm{CI}$ & $p$ \\
\hline $\begin{array}{l}\text { Preferred age of retirement } \\
\text { (continuous) }\end{array}$ & 2.20 & $1.67-2.89$ & $<0.001$ & 0.54 & $0.43^{-0.67}$ & $<0.001$ \\
\hline Female & 1.00 & Ref. & & 1.00 & Ref. & \\
\hline Male & 1.28 & $0.5^{2-3.13}$ & 0.59 & 0.76 & $0.39^{-1.4^{6}}$ & 0.40 \\
\hline Age (continuous) & 0.55 & $0.43^{-0.70}$ & $<0.001$ & 1.66 & $1.35^{-2.04}$ & $<0.001$ \\
\hline$\geqslant$ University/college & 1.00 & Ref. & & 1.00 & Ref. & \\
\hline$\leqslant$ High school & 3.13 & $1.21-8.12$ & 0.01 & 1.07 & $0.54^{-2.13}$ & 0.84 \\
\hline Not married & 1.00 & Ref. & & 1.00 & Ref. & \\
\hline Married & $0.5^{6}$ & $0.19^{-1} .5^{6}$ & 0.29 & o.69 & $0.28-1.66$ & 0.40 \\
\hline No children & 1.00 & Ref. & & 1.00 & Ref. & \\
\hline Children & 1.14 & $0.3^{1-4.25}$ & 0.84 & 0.80 & $0.30-2.07$ & 0.64 \\
\hline Good self-rated health & 1.00 & Ref. & & 1.00 & Ref. & \\
\hline Poor self-rated health & 4.26 & $1.5^{2-11.93}$ & $<0.01$ & 1.15 & $0.5^{0-2.65}$ & 0.74 \\
\hline White-collar work & 1.00 & Ref. & & 1.00 & Ref. & \\
\hline Blue-collar work & 2.83 & $1.08-7 \cdot 4^{0}$ & 0.03 & 1.32 & $0.67-2.62$ & $0.4^{2}$ \\
\hline 1st quartile income & 1.00 & Ref. & & 1.00 & Ref. & \\
\hline 2nd quartile income & 1.37 & $0.42-4.43$ & o.6o & 1.66 & $0.70-3.94$ & 0.25 \\
\hline 3rd quartile income & $2.5^{\mathrm{O}}$ & o.68-9.16 & 0.17 & 2.83 & $1.08-7 \cdot 4^{1}$ & 0.03 \\
\hline $4^{\text {th }}$ quartile income & 4.08 & $1.11-14.94$ & 0.03 & 1.24 & $0.4^{6}-3 \cdot 3^{2}$ & 0.67 \\
\hline
\end{tabular}

Notes: $\mathrm{N}=309 . R^{2}=0.30,22$ degrees of freedom, $p<0.001$. OR: odds ratio. CI: confidence interval. Ref.: reference category (those who retired at the preferred age).

Interaction terms between preferred retirement age and the other covariates indicated that the likelihood of earlier than preferred retirement increased as preferred retirement age increased $(p=0.03)$, whereas the reverse was true for later than preferred retirement $(p<0.01)$ (not shown). The likelihood for blue-collar workers and workers in poor health retiring earlier than preferred was reduced with increasing preferred retirement age ( $p<0.01$ and $p<0.001$, respectively) (not shown).

Analyses stratified by type of work showed that the likelihood of retiring earlier than preferred increased, to a greater extent for white-collar workers than for blue-collar workers, as preferred retirement age increased $\left(\mathrm{OR}=6.84\left(\mathrm{CI}=2.23^{-20.95}\right)\right.$ versus $\left.\mathrm{OR}=1.8 \mathrm{o}\left(\mathrm{CI}=1.3^{2-2.45}\right), p<0.01\right) . \mathrm{No}$ difference existed between the groups in the risk of retiring later than preferred (not shown). Likewise, workers in good health appeared to have an increased risk of earlier than preferred retirement as preferred retirement age increased $(\mathrm{OR}=2.7 \mathrm{O}, \mathrm{CI}=1.89-3.87)$, whereas no such effect was observed for workers in poor health (not shown). 
The presumed strongest measure of intention explored was related to whether individuals had decided when to retire. Decisions were anticipated to correlate strongest with actual retirement behaviour. Table 5 shows the percentage distribution of retired persons by decided retirement age. The correlation between decided age of retirement, as stated at $\mathrm{T}_{1}$, and actual age of retirement, as stated at $\mathrm{T}_{2}$, was strong $(r=0.63)$. The decided age of retirement explained 40 per cent $\left(0.63^{2}\right)$ of the variation in actual retirement age. As judged by correlations calculated on the continuous variables, the exact decided age and exact retirement age, a stated decision about retirement seemed to predict the actual retirement behaviour better than did a stated preferred retirement age $\left(r^{2}=0.40\right.$ and 0.26 , respectively, $p=0.03$, Fisher $r$-to- $z$ transformation, one-tailed). This finding supports the fact that a larger proportion of workers acted according to their decisions (45 per cent; Table 5), than according to their preference (26 per cent; Table 3). Further, 6o per cent of those who decided to retire at 62 actually did so, compared to only 38 per cent of those who preferred to retire at $62(p=0.02)$. For the older age groups, when looking at preferences and decisions to retire at 67 years of age, minor and non-significant differences existed (5o per cent versus 45 per cent).

In both the univariate (Table 5) and multivariate (Table 6) models, an older decided retirement age was predictive of earlier than decided actual retirement $(\mathrm{OR}=2.29)$ and a lower risk of retiring later than decided $(\mathrm{OR}=0.77)$. Additionally, older age reduced the risk of retiring earlier than decided $(\mathrm{OR}=0.6 \mathrm{o})$ and increased the risk of retiring later than decided $\left(\mathrm{OR}=1.4^{2}\right)$. Net of decided retirement age, holding a blue-collar occupation increased the risk of earlier than decided retirement $(\mathrm{OR}=3.18)$, whereas poor self-rated health only revealed a tendency to increase the risk for earlier than decided retirement (not statistically significant).

Interaction terms between decided retirement age and the other covariates suggest the likelihood of earlier than decided retirement increased with increasing decided retirement age $(p=0.04)$, whereas a reverse tendency for later than decided retirement was not statistically significant $(p=0.07)$ (not shown). The likelihood for workers in poor health to retire earlier than decided was reduced with increasing decided retirement age $(p<0.01)$ (not shown). Analyses stratified by health showed that the likelihood of retiring earlier than decided was elevated only for workers in good health with older decided retirement ages $(\mathrm{OR}=3.28$, CI $1.88-5 \cdot 75$ ). Workers in poor health had no increased risk of earlier than decided retirement (not shown). 


\section{Per Erik Solem et al.}

T А В L Е 5. A comparison of stated decided retirement age/other covariates (2002-03) and actual retirement age (2007-o8) for employees 57 years and older in 2002-03 who were retired in 2007-08

\begin{tabular}{|c|c|c|c|c|c|}
\hline & $\begin{array}{l}\text { Retired } \\
\text { earlier than } \\
\text { decided }\end{array}$ & $\begin{array}{l}\text { Retired at the } \\
\text { decided age }\end{array}$ & $\begin{array}{c}\text { Retired later } \\
\text { than } \\
\text { decided }\end{array}$ & Total & $p$ \\
\hline & \multicolumn{4}{|c|}{ Percentages (N) } & \\
\hline $\begin{array}{l}\text { Preferred age of } \\
\text { retirement: }\end{array}$ & & & & & $<0.001$ \\
\hline $54^{-61}$ & 0.0 & $55 \cdot 6$ & $44 \cdot 4$ & $100(9)$ & \\
\hline 62 & 21.0 & $59 \cdot 7$ & $19 \cdot 4$ & $100(62)$ & \\
\hline $63-66$ & 10.9 & 29.1 & 60.0 & $100(55)$ & \\
\hline 67 & 22.9 & $5^{0.0}$ & 27.1 & $100(48)$ & \\
\hline $68-90$ & 80.0 & 0.0 & 20.0 & $100(10)$ & \\
\hline Female & 12.8 & $4^{6.5}$ & $4^{0.7}$ & $100(86)$ & \\
\hline Male & 27.6 & $4^{2.9}$ & 29.6 & $100\left(9^{8}\right)$ & 0.04 \\
\hline$\leqslant$ High school & $25 \cdot 0$ & $44 \cdot 0$ & 31.0 & $100(116)$ & \\
\hline$\geqslant$ University/college & 13.2 & $45 \cdot 6$ & $4^{1.2}$ & $100(68)$ & 0.13 \\
\hline Not married & 22.5 & $37 \cdot 5$ & 40.0 & $100(40)$ & \\
\hline Married & 20.1 & $4^{6.5}$ & $33 \cdot 3$ & $100(144)$ & 0.59 \\
\hline No children & 34.8 & 34.8 & 30.4 & $100(23)$ & \\
\hline Children & 18.6 & $4^{6.0}$ & $35 \cdot 4$ & $100(161)$ & 0.20 \\
\hline Good self-rated health & 18.8 & 47.0 & 34.2 & $100(149)$ & \\
\hline Poor self-rated health & 28.6 & $34 \cdot 3$ & 37.1 & $100(35)$ & 0.30 \\
\hline White-collar work & 13.5 & $49 \cdot 4$ & $37 \cdot 1$ & $100(89)$ & \\
\hline Blue-collar work & $27 \cdot 4$ & 40.0 & 32.6 & $100(95)$ & 0.06 \\
\hline 1st quartile income & $17 \cdot 4$ & $39 \cdot 1$ & $43 \cdot 5$ & $100(46)$ & \\
\hline 2nd quartile income & 26.1 & $5^{0.0}$ & $23 \cdot 9$ & $100\left(4^{6}\right)$ & \\
\hline 3rd quartile income & 13.0 & $43 \cdot 5$ & $43 \cdot 5$ & $100\left(4^{6}\right)$ & \\
\hline $4^{\text {th }}$ quartile income & 26.1 & $45 \cdot 7$ & 28.3 & $100\left(4^{6}\right)$ & 0.27 \\
\hline Total & 20.7 & 44.6 & 34.8 & $100(184)$ & \\
\hline
\end{tabular}

In summary, decisions to retire at a certain age are better predictors of actual retirement age than are preferences for retirement at a certain age among workers 57 years and older. Preferences and decisions for the specific ages of 62 and 67 are better predictors of retiring at the targeted age compared to preferences or decisions for any other ages.

\section{Discussion}

We hold considering continuing to work as the weakest intention and found that this measure was the poorest predictor of actual retirement behaviour. A positive correlation existed between considering continuing to work and actually doing so $(r=0.20)$; however, the point estimate was low, albeit statistically significant. The question of whether an older worker will 
T А В L E 6 . Estimates from a fully adjusted multinomial logistic regression model to assess the probability of retiring at an earlier or later age than decided

\begin{tabular}{|c|c|c|c|c|c|c|}
\hline \multirow[b]{2}{*}{ Status in $2002-03$} & \multicolumn{3}{|c|}{ Earlier than decided } & \multicolumn{3}{|c|}{ Later than decided } \\
\hline & OR & $95 \%$ CI & $p$ & OR & $95 \% \mathrm{CI}$ & $p$ \\
\hline $\begin{array}{l}\text { Decided age of retirement } \\
\text { (continuous) }\end{array}$ & 2.29 & $1.55^{-3.39}$ & $<0.001$ & 0.77 & $0.5^{8-1.00}$ & 0.05 \\
\hline $\begin{array}{l}\text { Female } \\
\text { Male }\end{array}$ & $\begin{array}{l}1.00 \\
2.84\end{array}$ & $\begin{array}{l}\text { Ref. } \\
\text { o.86-8.44 }\end{array}$ & 0.06 & $\begin{array}{l}1.00 \\
1.01\end{array}$ & $\begin{array}{l}\text { Ref. } \\
0.4^{6-2.23}\end{array}$ & 0.98 \\
\hline Age (continuous) & 0.60 & $0.43^{-0.82}$ & $<0.01$ & $1.4^{2}$ & $1.11-1.82$ & $<0.01$ \\
\hline $\begin{array}{l}\geqslant \text { University/college } \\
\leqslant \text { High school }\end{array}$ & $\begin{array}{l}1.00 \\
1.62\end{array}$ & $\begin{array}{l}\text { Ref. } \\
0.55^{-4.78}\end{array}$ & 0.88 & $\begin{array}{l}1.00 \\
0.59\end{array}$ & $\begin{array}{l}\text { Ref. } \\
0.28-1.26\end{array}$ & 0.17 \\
\hline $\begin{array}{l}\text { Not married } \\
\text { Married }\end{array}$ & $\begin{array}{l}1.00 \\
0.5^{8}\end{array}$ & $\begin{array}{l}\text { Ref. } \\
0.17-1.97\end{array}$ & $0.3^{8}$ & $\begin{array}{l}1.00 \\
0.78\end{array}$ & $\begin{array}{l}\text { Ref. } \\
0.3^{1-1.99}\end{array}$ & 0.60 \\
\hline $\begin{array}{l}\text { No children } \\
\text { Children }\end{array}$ & $\begin{array}{l}1.00 \\
0.5^{1}\end{array}$ & $\begin{array}{l}\text { Ref. } \\
0.12-2.07\end{array}$ & 0.34 & $\begin{array}{l}1.00 \\
0.99\end{array}$ & $\begin{array}{l}\text { Ref. } \\
0.29-3.35\end{array}$ & 0.98 \\
\hline $\begin{array}{l}\text { Good self-rated health } \\
\text { Poor self-rated health }\end{array}$ & $\begin{array}{l}1.00 \\
2.75\end{array}$ & $\begin{array}{l}\text { Ref. } \\
\text { o.88-8.61 }\end{array}$ & 0.08 & $\begin{array}{l}1.00 \\
1.30\end{array}$ & $\begin{array}{l}\text { Ref. } \\
0.5^{2-3.29}\end{array}$ & $0.5^{8}$ \\
\hline $\begin{array}{l}\text { White-collar work } \\
\text { Blue-collar work }\end{array}$ & $\begin{array}{l}1.00 \\
3.18\end{array}$ & $\begin{array}{l}\text { Ref. } \\
0.99^{-10.34}\end{array}$ & 0.05 & $\begin{array}{l}1.00 \\
1.35\end{array}$ & $\begin{array}{l}\text { Ref. } \\
0.62-2.97\end{array}$ & 0.45 \\
\hline $\begin{array}{l}\text { 1st quartile income } \\
\text { 2nd quartile income } \\
3^{\text {rd quartile income }} \\
4^{\text {th quartile income }}\end{array}$ & $\begin{array}{l}1.00 \\
1.61 \\
0.55 \\
1.33\end{array}$ & $\begin{array}{l}\text { Ref. } \\
0.4^{1-6.33} \\
0.11-2.7^{1} \\
0.3^{0}-5.9^{6}\end{array}$ & $\begin{array}{l}0.5^{0} \\
0.4^{6} \\
0.71\end{array}$ & $\begin{array}{l}1.00 \\
0.41 \\
0.73 \\
0.55\end{array}$ & $\begin{array}{l}\text { Ref. } \\
0.15^{-1.16} \\
0.26-2.01 \\
0.17^{-1.78}\end{array}$ & $\begin{array}{l}0.09 \\
0.54 \\
0.32\end{array}$ \\
\hline
\end{tabular}

Notes: $\mathrm{N}=184 . R^{2}=0.30,22$ degrees of freedom, $p<0.001$. OR: odds ratio. CI: confidence interval. Ref.: reference category (those who retired at the decided age).

consider continuing to work is far from a perfect proxy to determine which individuals actually continue working after having reached an age at which one may opt to retire.

Considerations up to five years in advance of continuing to work beyond the optional retirement age may not be based on critical reflections about the future opportunity structure. In fact, these opportunities may be misjudged or change (Prothero and Beach 1984), and one's entire life situation may alter before the optional retirement age is reached. In addition, if intentions are ambivalent, the preference for retirement or continued work may change when the option to retire becomes imminent (Miller 1959; Solem 1989). Furthermore, critical reflections and a realistic comprehension of the pertinent aspects of a situation and prospects for the future may be overruled by irrational influences on behaviour (Brown and Vickerstaff 2011; Kahneman 2011).

The preference for a specific retirement age seems, as expected, to have stronger effects on retirement behaviour than does less fixed considerations, 
and decisions to retire at a specific age exhibit even stronger predictive power than do preferences. The predictive power appears to vary depending on the decision. The majority of older workers deciding to retire at the age of 62 followed their decision and more often than did those preferring to retire at 62. However, both preferences and decisions predicted behaviour better when the targeted age of retirement was 62 or 67 , which at the time of this study, were the eligible ages for contractual early pension (62) and standard old age pension $(67)$. Preferences and/or decisions and behaviour may be directed towards those ages because of normative beliefs (Ajzen 1988). Therefore, it is necessary to caution the use of both preferences for and decisions about retirement age as proxies for actual age of retiring, and even more so if the targeted age differs from the eligibility age for early pension (62) or standard old age pension $(67)$.

Intentions and behaviour were observed among older workers who could opt to retire within the five-year observation period. Preferences and decisions stated closer to the age of actual retirement were expected to be more exact. Unfortunately, in exploring this possibility, our sample size proved insufficient because fewer age cohorts could be included. On the other hand, statements collected very close to the time of optional retirement (i.e. valid for very short time gaps only), would be much less useful for policy makers and planners compared to using observed, actual retirement behaviour. Importantly, up to five years in advance, more people are able to state a preference ( 92 per cent) rather than make a decision ( 55 per cent), and preferences appear to be the better choice in attempting to predict retirement behaviour among senior workers in Norway.

Predictions improve when moving from general considerations about early retirement to statements of retirement at a specific age, whether the age is preferred or decided. As mentioned, this finding holds particularly true for preferences and decisions to retire at the normative ages of 62 and 67 . A better prediction for specific ages may be explained by Ajzen's (1988, 2011 ) observation, namely that attitudes predict behaviour better when an explicit target of the attitude is specified.

The correspondence between intentions concerning retirement and actual behaviour of retiring is supposedly influenced by the opportunity structure, as evidenced by the finding that 79 per cent of older workers preferred to retire before the age of 62 and actually retired later than they preferred. An equal proportion of older workers preferring to retire later than 67 retired earlier than they preferred. These older workers preferred to retire at ages outside the normative limits. Those preferring early retirement were restricted by eligibility rules, thus, earlier retirement was outside their control. The only other option for these individuals within the welfare state would be taking a disability pension. It would be interesting 
in future research to assess whether the probability of taking disability pension differed from those who preferred or decided on later retirement. Those preferring late retirement may be restricted by mandatory retirement ages or by normative beliefs about the appropriate age to retire. Thus, the targeted year for retirement influences the degree of correspondence between intentions and behaviour.

A lower preferred retirement age and higher attained age predict later than preferred retirement. At the same time, both a higher preferred retirement age and lower attained age predict earlier than preferred retirement. Additionally, low education, blue-collar work and poor selfrated health predict earlier than preferred retirement. Our sample size was too small to explore fully the reasons behind the predictive power of the covariates. Future research ought to address differences in the opportunity structures within different 57 years and older age groups. Differential patterns are likely to exist, however, as the workers with low education may be restricted by sub-optimal competencies or work abilities that may make them less attractive among employers, whereas highly educated workers may be assets to their employers, which could protect them against earlier than preferred retirement.

Poor health is an obvious limitation for remaining in the labour market as long as preferred. Good health as well may serve as a reason for early exit (e.g. when reasons to retire include fulfilling other life goals while still healthy or to preserve and promote good health) (Pond, Stephens and Alpass 2010). However, older workers with poor health exit the labour market earlier than do workers in good health. Workers with poor health even quit working earlier than they would prefer. The same is true for blue-collar workers. On the other hand, stratified analyses showed that the likelihood of earlier than preferred retirement increased as the preferred retirement age increased to a larger extent for white-collar workers and workers in good health compared to blue-collar workers and workers in poor health. This finding indicates constraints on late retirement even for white-collar workers and workers in good health.

Later than preferred retirement is less likely with increasing preferred retirement age, independent of health and type of work. However, because health and preferred age of retirement were measured at $\mathrm{T}_{1}$, both variables may have changed before actual retirement took place. Specifically, the worker's health may have worsened and the preferences for work may have changed according to their declining abilities to work. Nevertheless, workers with poor health at $\mathrm{T} 1$ often preferred an age of retirement that was not achieved. This finding alludes to a possible sub-optimal inclusion of older workers with health problems in working life, where modifications or interventions may be appropriate. This idea clearly warrants further research. 


\section{Per Erik Solem et al.}

For retiring earlier or later than decided, we found similar patterns as we did for preferences. However, in addition to an older decided age for retirement and an older attained age, only blue-collar work predicted earlier than decided retirement. Blue-collar workers retired earlier than did white-collar workers; however, they often decided to retire later than they actually did. Blue-collar workers may be a group for whom policy changes to enable prolonged workforce participation could yield significant results.

Using stratified analyses, we found that the likelihood of retiring earlier than decided elevated with increasing decided retirement ages only for workers in good health, which indicates that, at older ages, even workers in good health encounter constraints against retiring as late as they decided. Legislation and agreements about mandatory retirement may represent such constraints.

We found few gender differences; however, when controlling for confounders such as income, type of work and education, male workers tended to retire earlier than did female workers. Additionally, no gender differences existed in retiring earlier or later than preferred, whereas male workers, more often than female workers, retired earlier than they decided. Further studies are needed to explore the mechanisms behind these patterns. However, the main finding concerning gender was that, in a Norwegian context, gender differences in retirement patterns are small.

\section{Conclusion}

In this study, we found significant correlations between retirement intentions and retirement behaviour within a five-year period. The strength of the correlations varied according to the strength of intentions. Contemplating to retire later than the eligible age for early pension predicted later actual retirement only modestly $(r=0.20)$. Preferring to retire at a selfspecified age improved the prediction of actual timing of retirement $\left(r=0.5^{1}\right)$, and having decided to retire at a certain age improved this prediction further $(r=0.63)$. The effect of intention strength was as expected. An important contribution of the study was that labour market resources (i.e. health, education) not only influence timing of retirement, but even the connection between intentions to retire and retirement behaviour. Workers with low education and those with poor health tend to have fewer opportunities to remain in the workforce as long as they prefer. Thus, workers with low access to resources do not necessarily retire early because they, more than workers in good health and those with high education, prefer to retire early. Blue-collar workers, more often than white-collar workers, may retire earlier than they had decided because they have fewer opportunities to remain working as long as they had decided. When 
preferring to retire at an older age, even white-collar workers and those in good health retire earlier than preferred, and workers in good health who have decided to retire late, retire even earlier than decided. Thus, constraints seem to apply even for workers in good health who wish to retire late. The role of mandatory retirement as a possible substantial barrier warrants further research. Equally important is future research on the opportunity structure for older workers with poor access to resources and how their resources could be strengthened, e.g. by health-promoting working environments, better inclusion of older workers in training at the workplace or adapting working conditions to the resources that workers possess.

\section{Acknowledgement}

The research was funded by The Research Council of Norway (project 201536/S20).

\section{References}

Ajzen, I. 1988. Attitudes, Personality and Behaviour. Open University Press, Milton Keynes, UK.

Ajzen, I. 2011. Job satisfaction, effort, and performance: a reasoned action perspective. Contemorary Economics, 5, 4, 32-43.

Anderson, K., Burkhauser, R. V. and Quinn, J. F. 1986. Do retirement dreams come true? The effect of unanticipated events on retirement plans. Industrial and Labor Relations Review, 39, 4, 518-26.

Becker, G. S. 1976. The Economic Approach to Human Behavior. University of Chicago Press, Chicago.

Beehr, T. A. 1986. The process of retirement: a review and recommendations for future investigation. Personnel Psychology, 39, 1, 31-55.

Brandtstädter, J., Rothermund, K., Kranz, D. and Kühn, W. 2010. Final decentrations: personal goals, rationality perspectives, and the awareness of finitude. European Psychologist, 15, 2, $15^{2-63}$.

Brown, P. and Vickerstaff, S. 2011. Health subjectivities and labor market participation: pessimism and older workers' attitudes and narratives around retirement in the United Kingdom. Research on Aging, 33, 5, 529-50.

Carstensen, L. L. 2006. The influence of a sense of time on human development. Science, 312, 5782, 1913-5.

Christensen, A. M., Fredriksen, D., Lien, O.C. and Stølen, N. M. 2012. Pension reform in Norway: combining an NDC approach and distributional goals. In Holzman, R., Palmer, E. and Robalino, D. (eds), Nonfinancial Defined Contribution Pension Schemes in a Changing Pension World. The World Bank, Washington DC, 129-57.

Cohen, J. 1988. Statistical Power Analysis for the Behavioral Sciences. (2nd ed). Erlbaum, Hillsdale N.J.

D'Addio, A. C., Keese, M. and Whitehouse, E. 2010. Population ageing and labour markets. Oxford Review of Economic Policy, 26, 4, 613-35.

Dijksterhuis, A., Bos, M. W., Nordgren, L. F. and van Baaren, R. B. 20o6. On making the right choice: the deliberation-without-attention effect. Science, 311, 5763, $1005^{-7}$. 
Ekerdt, D.J. 2010. Frontiers of research on work and retirement. Journals of Gerontology: Social Sciences, 65 $\mathbf{B}, 1,69-80$.

Ekerdt, D. J., Hackney, J., Kosloski, K. and DeViney, S. 2001. Eddies in the stream: the prevalence of uncertain plans for retirement. Journals of Gerontology: Social Sciences, $\mathbf{5 6 B}, 3, \mathrm{~S}_{1} 62-7 \mathrm{O}$.

Feldman, D. C. and Beehr, T. A. 2011 . A three-phase model of retirement decision making. American Psychologist, 66, 3, 193-203.

Henkens, K. and Tazelaar, F. 1997. Explaining retirement decisions of civil servants in the Netherlands. Research on Aging, 19, 2, 139-73.

Jex, S. M. and Grosch, J. 2013. Retirement decision making. In Wang, M. (eds), The Oxford Handbook of Retirement. Oxford University Press, Oxford, 267-79.

Kahneman, D. 201 1. Thinking, Fast and Slow. Farrar, Straus and Giroux, New York.

Kjønstad, A. 2012 . Folketrygdens alderspensjoner. Jussens Venner, 47, 2, 85-157.

Leiulfsrud, H., Bison, I. and Jensberg, H. 2005. European Social Survey: Computing Social Class Indicies. Available online at http://www.europeansocialsurvey.org/search? $\mathrm{q}=$ computing+social+class [Accessed 17 October 2013].

Lewin, K. 1935. A Dynamic Theory of Personality. McGraw-Hill, New York.

Lima, I. 2011. EGP-skalaen for sosial klasse i NorLAG/LOGG. ACCESS Arbeidsnotat. Norwegian Social Research, NOVA, Oslo.

Loretto, W., Vickerstaff, S. and White, P. 2007. The Future for Older Workers. New Perspectives. The Policy Press, Bristol, UK.

Micheel, F., Roloff, J. and Wickenheiser, I. 2010. The impact of socioeconomic characteristics on older employees' willingness to continue working in retirement age. Comparative Population Studies-Zeitschrift für Bevölkerungswissenschaft, 35, 4, $869-901$.

Midtsundstad, T. 2006. Hvordan bidra til lengre yrkeskarrierer? Erfaringer fra norsk og internasjonal forskning om tidligpensjonering og seniortiltak. Fafo Report 534, Fafo, Oslo.

Miller, N.E. 1959. Liberalization of basic S-R concepts: extensions to conflict behavior, motivation, and social learning. In Koch, S. (ed.), Psychology: A Study of a Science. Volume 2, McGraw-Hill, New York, 196-292.

Moen, P. 2012. Retirement dilemmas and decisions. In Hedge, J. W. and Borman, W. C. (eds), The Oxford Handbook of Work and Aging. Oxford University Press, Oxford, 549-69.

O’Donnell, O., Teppa, F. and van Doorslaer, E. 2008. Can subjective survival expectations explain retirement behaviour? Working Paper 188, De Nederlandsche Bank, Amsterdam.

Örestig, J., Strandh, M. and Stattin, M. 2013. A wish come true? A longitudinal analysis of the relationship between retirement preferences and the timing of retirement. Journal of Population Ageing, 10, 1, 25-35.

Organisation for Economic Co-operation and Development (OECD) 2011 a. Pensions at a Glance 20I I: Retirement-income Systems in OECD and G2o Countries. Available online at http://dx.doi.org/10.1787/pension_glance-2011-en [Accessed 13 October 2013].

Organisation for Economic Co-operation and Development (OECD) 2011 b. Employment Outlook. Available online at http://www.oecd.org/document/2/o,3746, en_2649_33729_48614146_1_1_1_1,oo.html [Accessed 13 October 2013].

Phillipson, C. 201 1. Extending working life and re-defining retirement: problems and challenges for social policy. In Ennals, R. and Salomon, R. H. (eds), Older Workers in a Sustainable Society. Peter Lang Verlag, Frankfurt am Main, Germany, 233-43.

Phillipson, C. and Smith, A. 2005. Extending working life: a review of the research literature. Research Report 299, Department for Work and Pension, London. 
Pond, R., Stephens, C. and Alpass, F. 2010. How health affects retirement decisions: three pathways taken by middle-older aged New Zealanders. Ageing E Society, 3o, $3,527-45$.

Prothero, J. and Beach, L. R. 1984. Retirement decisions: expectation, intention, and action. Journal of Applied Social Psychology, 14, 2, 162-74.

Quinn, J., Cahill, K. and Giandrea, M. 2011 . Early Retirement: The Dawn of a New Era? Policy Brief, July, TIAA-CREF Institute, New York. Available online at www.tiaacrefinstitute.org/public/institute/research/briefs/pb_earlyretiremento711.html [Accessed 13 October 2013].

Ruff, J. 2002. Information Overload: Causes, Symptoms and Solutions. LILA Briefing. Available online at http://www.newsmaster.be/flow/dw/ciel/2011/ aout1 1 /infooverloadbrief.pdf [Accessed 13 October 2013].

Shultz, K. S. and Wang, M. 2011 . Psychological perspectives on the changing nature of retirement. American Psychologist, 66, 3, 170-9.

Slagsvold, B., Veenstra, M., Daatland, S. O., Hagestad, G., Hansen, T., Herlofson, K., Koløen, K. and Solem, P. E. 201 2. Life-course, ageing and generations in Norway: the NorLAG study. Norwegian Journal of Epidemiology, 22, 2, 95-102.

Solem, P. E. 1989. Enighet og tvisyn. Om yrkesaktives holdninger til øvre aldersgrenser $i$ arbeidslivet. NGI-rapport 3-1989, Norsk gerontologisk institutt, Oslo.

Solem, P. E. 2007. Seniorer $i$ arbeidslivet. Kunnskap om aldring og arbeid. NOVA-rapport 16-o7, Norwegian Social Research (NOVA), Oslo.

StataCorp 2011. Stata I2: Stata Statistical Software: Release I2. StataCorp LP, College Station, Texas.

Taylor, P. 2010. Cross-national trends in work and retirement. In Dannefer, D. and Phillipson, C. (eds), The Sage Handbook of Social Gerontology. Sage, Los Angeles, $54{ }^{\circ}-5^{\circ}$.

Toffler, A. 1970. The Future Shock. Random House, New York.

Topa, G., Moriano, J.A., Depolo, M., Alcover, C. M. and Morales, J. F. 2009. Antecedents and consequences of retirement planning and decision-making: a meta-analysis and model. Journal of Vocational Behavior, 75, 1, 38-55.

van Solinge, H. and Henkens, K. 20og. Living longer, working longer? The impact of subjective life expectancy on retirement intentions and behaviour. European Journal of Public Health, 2o, 1, 47-51.

van Solinge, H. and Henkens, K. 2014. Work-related factors as predictors in the retirement decision-making process of older workers int the Netherlands. Ageing $\mathcal{E}^{\circ}$ Society, 34, 9, $155^{1-74}$.

Vickerstaff, S. and Cox, J. 2005. Retirement and risk: the individualisation of retirement experiences. Sociological Review, 53, 1, 77-95.

Vickerstaff, S., Loretto, W. and White, P. 2007. The future for older workers: opportunities and constraints. In Loretto, W., Vickerstaff, S. and White, P. (eds), The Future for Older Workers. New Perspectives. The Policy Press, Bristol, UK, 203-26.

Accepted 8 September 20I4; first published online 22 October 2014

Address for correspondence:

Per Erik Solem, NOVA,

Oslo and Akershus University College of Applied Sciences,

PO Box 3223 Elisenberg, o208 Oslo, Norway.

E-mail: per.e.solem@nova.hioa.no 